\title{
Consolidating Unorganised Retail Businesses through Digital Platforms: Implications for Achieving the UN Sustainable Development Goals
}

\author{
Malobi Mukherjee *(1) and Jacob Wood
}

check for updates

Citation: Mukherjee, M.; Wood, J. Consolidating Unorganised Retail Businesses through Digital Platforms: Implications for Achieving the UN Sustainable Development Goals. Sustainability 2021, 13, 12031. https:// doi.org/10.3390/su132112031

Academic Editor: Andrea Appolloni

Received: 24 September 2021

Accepted: 27 October 2021

Published: 31 October 2021

Publisher's Note: MDPI stays neutral with regard to jurisdictional claims in published maps and institutional affiliations.

Copyright: (C) 2021 by the authors. Licensee MDPI, Basel, Switzerland. This article is an open access article distributed under the terms and conditions of the Creative Commons Attribution (CC BY) license (https:/ / creativecommons.org/licenses/by/ $4.0 /)$.
James Cook University Business School, James Cook University, Singapore 387380, Singapore; jacob.wood@jcu.edu.au

* Correspondence: malobi.mukherjee@jcu.edu.au

\begin{abstract}
This study explores whether digitalisation of unorganised retail (UR) businesses in emerging markets have a positive socio-economic impact on the lives of the subsistence consumermerchants who perform the dual role of being, not only consumers providing for themselves and their families, but also the managers of micro-UR businesses. We develop a framework for sustainable business model innovation at the base of the pyramid by undertaking content analysis of 65 newspaper articles (interviews with senior executives and founders of digital app-based platforms, expert analysis) as well as social media and YouTube testimonials of UR business users of these platforms in Vietnam, Indonesia, Malaysia and the Philippines. Using the Gioian coding structure of open and second order comparative coding, we develop a framework for sustainable business model innovation from the base of the pyramid perspective. The framework captures how digitalisation enables the UR businesses to circumvent resource shortages, consolidate procurement and inventory management and diversify product and service offerings, which leads to significant economic and social transformation for both the micro enterprises and their owners. Our framework contributes to the emergent literature on sustainable business model innovation and inclusive innovation in resource-constrained contexts. We conclude that sustainable business model innovations enable socio-economic transformations similar to those experienced by UR businesses in emerging Asian markets. Such developments can create local level pathways for local tropical countries seeking to achieve UN social development goals.
\end{abstract}

Keywords: unorganised retailers; sustainable business model innovation; base of the pyramid business models; resource constraints; UN Sustainable Development Goals; tropical countries; emerging markets

\section{Introduction}

The objective of this paper is to develop a theoretical framework exploring the impact of digitisation on unorganised retail (UR) businesses and the implications for sustainable business model innovations at the base of the pyramid. A business model constitutes 'what a firm is and does' [1,2]. Increasingly, the business model literature has focused on integrating sustainability aspects into business design and implementation [3,4]. Simultaneously, changes in the global economy owing to overall economic downturns, technological disruptions, climate change, resource scarcity [3] and the resultant sustainable development agenda has given rise to a stream of sustainable business model innovation literature. Recent literature [1,5] has explored the role of technological interventions in business consolidation. There is also burgeoning literature [6,7] exploring the impact of app-based technological intervention in improving the economic performance of UR firms in emerging markets. Within this context, Gupta and Ramachandran [8] highlight the scope for exploring how technological intervention can improve efficiencies in UR business operations reliant largely on traditional supply chains, manual records of credit and in-store inventory 
and lack websites or online services. The UR retail context is particularly relevant to the emerging literature on sustainable base of pyramid business model innovation because large sections of the base of pyramid population (with daily earnings of USD 1.90-3.20) manage these businesses in emerging markets [9]. The majority of the existing research on sustainable business model innovation has studied business model design in relatively mature and stable institutional environments with sufficient infrastructure and access to resources [10]. In contrast, the literature on sustainable business model evolution at the base of pyramid, which is characterised by chronic resource and infrastructural constraints, has very few studies focusing on the economic [6,7] and social transformation [11] resulting from technological intervention. To address this gap in the literature, we posed the following research questions: (1) How can digitisation enable UR businesses to consolidate their business operations and improve overall economic performance and (2) how can the digitisation of UR businesses enable inclusive and transformative sustainable business model innovation at the base of the pyramid?

To answer these questions, we conducted a secondary research study on the digitalisation of UR businesses in four South East Asian emerging markets. Using the Gioian [12] coding structure (first and second order coding), we collated the responses of app founders and independent retail analysts from 65 newspapers articles. We cross-validated these responses with app user perspectives from corporate and independent social media sites, to assess the impact of digitalisation on UR businesses. From this, we developed a grounded process framework capturing the socio-economic transformation of UR businesses and their owners. Our resultant framework highlights that digitalisation of business operations enables UR businesses to overcome fundamental inefficiencies by consolidating procurement, automating in-store transactions and inventory management, and the diversification of product and service offerings. Overcoming inherent business inefficiencies by consolidating business operations results in improved economic performance of the UR businesses, transforms livelihoods of the UR business owners and creates local level pathways for the realisation of the UN SDGs [13]. With this framework, we reconcile the literature between sustainable business model innovation $[1,3,6,8]$ and transformative models of innovation in emerging economies $[11,14]$, emphasising that digitisation enables UR businesses to circumvent chronic resource shortages that improve business performance, which in turn leads to further socio-economic transformation. This is important because the research highlights that local level pathways in resource constrained emerging market environments can 'level-up' development to attain the UN Sustainable Development Goals (SDG) [13] without waiting on necessary governmental intervention for resource availability.

The study is organised as follows. After the Introduction, Section 2 provides an overview of the relevant and most contemporary literature on sustainable business model innovation in resource-constrained emerging markets. Section 3 then provides a detailed discussion of the research methodology, including an elaboration of the analytical approach adopted. Following this, Section 4 introduces our findings by describing the first order codes, the second order codes and the aggregate dimensions generated from the analysis. Section 5 discusses the sustainable business model framework and contribution in relation to the existing literature. Section 6 summarises the theoretical implications of the research and Section 7 outlines the practical implications. Finally, in Section 8, we highlight the limitations of this paper before presenting opportunities for further research and make some concluding remarks.

\section{Sustainable Business Model Innovation in Emerging Market UR Businesses}

\subsection{Sustainable Business Model Innovation}

Sustainable business model innovation provides a new perspective on integrating sustainability aspects into business design and implementation [3,4]. Within the relevant literature, research on economic sustenance [1,5] focuses on strategic transformation through consolidation of business processes and competitive strength. Holström, [1] highlights the role of businesses process consolidation when organisations forge alliances, mergers 
and acquisitions to leverage each other's competitive strengths for economic sustenance. Langley and Leyshon [5] highlight the role of innovative FinTech platforms and their unique ability to link together and consolidate multiple network effects, thereby building up an ecosystem of goods and services and closing off competitors. More recently, business model innovation has become a prevalent concept to capture new configurations of business model evolution enabled by technological progress, new customer preferences and deregulation $[10,15]$. Simultaneously, changes in the global economy owing to overall economic downturns, technological disruptions, climate change, resource scarcity [3] and the resultant sustainable development agenda has given rise to a stream of sustainable business model innovation literature.

Several manifestations of sustainable business model innovation, with economic, social and environmental implications, have been discussed in the literature [3]. These include integrative business models which balance all three aspects of sustainability [16], sharing economy models which facilitate temporary access to scarce resources through sharing platforms [17] and product system models which aim to provide customer satisfaction while fostering sustainability [18]. Other authors [19,20] introduce business models built on the principles of circularity inspired by the philosophy of lean-ness, which aims to maximise customer value by minimising waste. Then there are social business models which focus on the achievement of social goals for market participants [21] and the base of pyramid business models that aim to alleviate poverty and increase profitability through radical innovations that cater to the needs of poor and vulnerable communities [2]. Examples of radical innovations include resource-constrained frugal, costs-based or good enough innovation aimed at producing affordable products for low-income consumers [22-29]. However, Sharmelly and Ray [22] also point out the challenges of economic sustenance (financial gains) for firms producing low cost and affordable products for subsistence consumers. Recent studies [6,7] highlight how the adoption of card-based, app-based payment options [6] and M-wallets, as well as account-based technologies [7], offer tech-enabled solutions for UR firms to overcome some of the challenges highlighted by Sharmelly and Ray [22]. Mortazavi et al. [11] offer a broader 'inclusive innovation' perspective, calling for the partnership between local entrepreneurs and governments, which helps firms cope with technological and economic changes in resource constrained contexts. Mihalache and Volberda [14] also refer to a co-evolutionary perspective of business innovation in emerging market contexts, in which firms are asked to develop new ways of doing business that not only improve the local (and global) competitiveness of the firm, but also improve the socio-economic situation of the socially embedded stakeholders.

Adhikary et al. [6] and Kumar et al. [7] provide an in-depth insight into the economic gains realised by UR businesses from the adoption of app-based digital payment solutions during their interaction with stakeholders and customers. In their review of UR businesses in emerging markets, Gupta and Ramachandran [8] highlight the scope for improving efficiencies in backend operations which largely rely on manual records of credit and instore inventory, traditional supply chain methods and a lack of websites or online services. Studies by Adhikary et al. [6] and Kumar et al. [7] assess the economic performance of UR businesses that have adopted mobile or app-based payments, while Gupta and Ramachandran [8] highlight the need for tech-enabled efficiencies in backend operations in order to improve business performance. Our paper seeks to overcome gaps identified in the Adhikary et al. [6] and Kumar et al. [7] studies by exploring how the adoption of an app or platform-based technologies might be able to consolidate and streamline the fragmented and inherently inefficient backend business operations of UR businesses to improve the economic performance. Moreover, we would also seek to explore whether the improved efficiencies in UR business would also have a positive socio-economic impact on the lives of the subsistence consumer-merchants who perform the dual role as consumers providing themselves and their families while also managing small UR businesses [9]. In doing so, we would seek to develop an inclusive [11] and transformative [14] view on sustainable business model innovation at the base of the pyramid involving UR businesses 
in emerging markets. Accordingly, the research questions we seek to answer in this study are as follows:

- How can the digitisation enable UR businesses to consolidate their business operations and improve overall economic performance?

- How can the digitisation of UR businesses enable inclusive and transformative sustainable business model innovation at the base of the pyramid?

\subsection{Unorganised Retail Businesses in Emerging Markets}

Unorganised Retailers (URs), comprising open kiosks and stalls, family-owned small stores and mom and pop stores [30], dominate the retail landscape across emerging markets, particularly in Asia [6,31]. According to Euromonitor [32], retail goods and services worth is an incredibly important component of the ASEAN economy, with some $27.8 \%$ of the population employed in the sector across the region. A key feature of the retail sector in emerging Asian and ASEAN countries is the co-existence of organised and URs, with the latter being the most prevalent retail format in these markets [8,31]. Several key studies $[8,31,33,34]$ highlight the fact that URs have continued to remain the dominant retail format in emerging markets despite the significant inroads made by modern retailers. A number of factors, including the convenience of time, location, the personalised relation with customers and high service levels [34,35], provide a unique market opportunity for URs despite competitive pressures from larger retailers. Despite them being operationally inefficient, with limited procurement, inventory, supply chain, sales and store operations [8], URs provide essential goods and services to their base of pyramid (consumer) communities who lack access to transportation and other consumption alternatives [8,36-39]. More fundamentally, these URs operate in an environment characterised by chronic shortage of infrastructural resources, including a shortage of physical storage space, a sporadic supply of electricity and water, as well as a fragmented supply of raw materials, all of which result in significant diseconomies of scale. These shortages create financial and infrastructural barriers to the adoption of technology $[8,10,40]$.

Despite a chronic resource shortage [40] in recent years, URs have undergone a technological evolution in the form of digital payments, comprising M-wallets, card-based payment technologies, account-based technologies and social security-based technologies [7,41]. According to the World Payments Report [42], published by Cap Gemini and BNP Paribas, the bulk of the digital payment technology growth has been in emerging markets. These consulting reports suggest that digital payment technologies will penetrate emerging markets by almost $19.6 \%$ per annum. It is also inevitable that this digitisation trend will accelerate in a post-COVID-19 world, as retailers seek to overcome the procurement and social distancing challenges posed by the virus [43]. Barring Adhikary et al. [6] and Kumar et al. [7], research into the impact of technological adoption on URs is scant [44]. The academic literature $[6,8,10,40]$ and consulting reports [45] reiterate the fact that the competitiveness and resilience of URs will be key to supporting dynamic, inclusive and sustainable forms of growth because of the significant economic and societal role they play in emerging markets. This inherent potential of the UR businesses therefore warrant further investigation and justify the key research questions of this study.

\section{Methodology}

\subsection{Research Context and Country Selection}

The authors focused on digitisation of UR businesses in the ASEAN region by drawing on examples from Indonesia, Vietnam, Malaysia and the Philippines, in particular. There are two specific reasons for choosing these countries as the focal point of this research. First, the small and traditional retailers in these four countries have been prolific in adopting innovative digital platforms to restructure their operations. In doing so, they are leapfrogging many of the developmental stages experienced by retailers in Europe and the US [46]. As such, Sanders et al. [46] have categorised Indonesia and Vietnam as the 'fast modernizers' of retail and primed them for disproportionate digital acceleration in the 
near future. Malaysia and the Philippines have been categorised by Sanders et al. [46] as 'developing digitalizers', which sees both countries on a tech-enabled trajectory towards retail maturity in the near future.

Second, the increased penetration of modern retail in these countries over the last year stood at $42 \%$ in Malaysia, 35\% in the Philippines, 19\% in Indonesia and 8\% in Vietnam [47]. Despite their modern retail developments, these rustic URs are omnipresent across urban and rural towns and continue to be the preferred retail channels compared to the modern store formats. According to Statista [48], in Indonesia, the traditional stores and wet markets were the preferred buying channel of $24 \%$ and $10 \%$ of the customers, respectively, while supermarkets and hypermarkets were the preferred channels for $7 \%$ and $11 \%$, respectively. In the Philippines, Statista [49] notes that mom and pop sari-sari stores accounted for $27.5 \%$ of food retail sales, compared to $9.67 \%$ in supermarkets and just under $4 \%$ in hypermarkets and convenience stores. In Vietnam, traditional grocery retailers accounted for over $90 \%$ of grocery sales, while the remaining $10 \%$ combined sales from supermarkets, convenience stores and hypermarkets was only about 3.5 million USD [50]. In Malaysia, $90 \%$ of businesses fall into the small and medium category and the focus of digitisation initiatives thereby affects retail trade as well [51]. Despite the internal infrastructural inefficiencies of these Asian markets and lack of technical prowess of the owners of the traditional stores, entrepreneurs have capitalised on the territorial and social embeddedness of these retailers through collaborative use of technology. This is paving the way for a more improvisational yet innovative path of retail development in these Asian countries, warranting further research in these unique contexts. Therefore, the researchers seek to investigate this unique path of retail development by adopting secondary desk research to review and analyse relevant market research and newspaper reports on the topic.

\subsection{Data Collection Using Secondary Desk Research}

In the first instance, we referred to four recent Statista reports [47-50] for an overview of projected retail sales, market shares and consumer preferences of UR retail channels to confirm our initial understanding of the current retail context. The resultant overview enabled us to justify our choice of the four Asian countries used in our study.

After identifying the countries of focal interest using Statista data, we selected keywords to search the ProQuest database for relevant newspaper articles on retail development in Asia for the period May 2019-May 2021. Our first keyword search for 'retail digital platforms in Asia' generated 4621 newspaper articles. Despite having identified the four countries from the Statista reports, we expanded our search to a pan-Asia context to ensure we had not missed any relevant cases from other Asian countries. This initial search generated articles on retail digitalisation in a number of Asian countries, with China and India being featured most prominently. However, the examples were primarily about generic e-commerce operations of Alibaba, Taobao, Amazon India, Flipkart and Reliance Jio, which was not the focus of our research. To eliminate these examples, we narrowed down our search by using the keyword search 'retail digital platform ASEAN' which generated 473 newspaper articles. We wanted to eliminate the newspaper articles on Singapore because it did not represent a resource constrained business context, and the examples from other ASEAN countries, Cambodia, Brunei, Laos and Thailand, did not generate examples of collaboration between digital platforms and UR businesses. In our final filtration we conducted a keyword search for news items on retail development in Vietnam, Indonesia, the Philippines and Malaysia and reduced the number of relevant studies to 158. The articles were then manually filtered to meticulously identify only those studies that discuss the actual strategic and operational impact of digital platforms on URs in the four countries. This manual filtration generated a final tally of 65 newspaper articles. The content of the 65 articles were then analysed using grounded theory methodology [52], which is considered appropriate for research projects where the purpose is to generate explanation (a theory) of a process, action or interaction shaped by the views of individuals involved in that process. It is particularly appropriate when the topic of research is at the 
nascent stages of development (as is the case with the impact of digitisation on emerging market UR businesses) and thereby requires theory development which is generated or grounded more firmly in data. Table 1 below provides the relevant details about the data which was used in this research.

Table 1. Data source.

\begin{tabular}{|c|c|c|}
\hline Sources of Data & Type of Data & Use in Analysis \\
\hline $\begin{array}{c}\text { Business press and news articles } \\
\text { generated from ProQuest Database } \\
\text { search } \\
\text { (all relevant URL links in } \\
\text { Appendix A) }\end{array}$ & $\begin{array}{l}\text { News articles about the e-commerce and } \\
\text { consumer trends in South East Asian emerging } \\
\text { markets (retrieved from Wall Street Journal, } \\
\text { Straits Times and World Economic Forum) News } \\
\text { articles about the app companies, including } \\
\text { interviews with the founders of the companies } \\
\text { (retrieved from BBC, Nikkei Asia, Straits Times, } \\
\text { Business Times, OECD, Jakarta Post, Jakarta Globe, } \\
\text { CNBC, Vietnamnet, Asian Business, Malaya Mail, } \\
\text { The Malaysian Reserve, Borneo Post, Manila Times, } \\
\text { Manila Standard) }\end{array}$ & $\begin{array}{l}\text { Gather data to enhance our } \\
\text { understanding and justify our choice } \\
\text { of the four South East Asian countries } \\
\text { for our research.Gathering data about } \\
\text { the core strategies, functions and } \\
\text { action taken by the app companies to } \\
\text { enable the UR owners. }\end{array}$ \\
\hline $\begin{array}{l}\text { Digital news media generated from } \\
\text { ProQuest data base search } \\
\text { (all relevant URL links in } \\
\text { Appendix A) }\end{array}$ & $\begin{array}{l}\text { News articles and blogs about the app } \\
\text { companies and interviews with independent } \\
\text { technology and retail analysts (retrieved from } \\
\text { Retail in Asia, KrASIA, E27, Marketing interactive, } \\
\text { TechCrunch, Campaign Brief Asia, vir.com, } \\
\text { supply chain lab blog, Deal Street Asia, The Edge } \\
\text { Markets, Absolute market.org, Digital News Asia, } \\
\text { The Full Frontal, The-ken.com, Business Inquirer, } \\
\text { Fintech news, Business Mirror, Wavemaker). }\end{array}$ & $\begin{array}{l}\text { Triangulate facts and responses of the } \\
\text { app companies to enhance validity of } \\
\text { insights, track independent responses } \\
\text { to actions taken by app provider. }\end{array}$ \\
\hline $\begin{array}{l}\text { YouTube Videos generated from } \\
\text { internet search } \\
\text { (all relevant URL links in } \\
\text { Appendix B) }\end{array}$ & $\begin{array}{c}\text { Interviews with Unorganised Retail (UR) owners } \\
\text { who have used the apps to digitalise their } \\
\text { businesses (three UR owners from Philippines, } \\
\text { two UR owners from Vietnam) }\end{array}$ & $\begin{array}{l}\text { Triangulate and validate facts and } \\
\text { observations reported in the news } \\
\text { media on the app companies with the } \\
\text { perspectives of the app users. }\end{array}$ \\
\hline $\begin{array}{l}\text { Social media and corporate websites } \\
\text { generated from internet search (all } \\
\text { relevant URL links in Appendix B) }\end{array}$ & $\begin{array}{l}\text { UR testimonials on corporate websites and } \\
\text { independent review sites (five Malaysian UR } \\
\text { owners, three Vietnamese UR owners, eight } \\
\text { Indonesian UR owners, six Filipino UR owners) }\end{array}$ & $\begin{array}{l}\text { Triangulate and validate facts and } \\
\text { observations reported in the news } \\
\text { media on the app companies with the } \\
\text { perspectives of the app users. }\end{array}$ \\
\hline
\end{tabular}

\subsection{Method of Analysis and Coding of Data}

To understand how digitisation enabled UR businesses operating in resource constrained contexts achieve socially and economically inclusive and transformative changes, we structured the data analysis in four distinct parts. In the first part, we collated the various accounts of app founders and app users from the newspaper articles, social media testimonials and YouTube videos to understand the operating context of the UR businesses and the strategic intent of digital intervention of the app founders. The second part of our analysis was aimed at identifying the action taken by the app providers to digitise the UR businesses and the impact on the UR business operations. To complete the first and second parts of the analysis, we performed multiple rounds of coding following Gioia et al. [12]. During coding (discussed in detail in the latter part of this section), we searched for macro categories describing challenges in the UR business context, which we had identified in the initial review of the literature. We extracted a list of (1) challenges faced by UR business practices as described by UR business owners and the founders of the digital apps and (2) actions taken by app founders to digitise the UR businesses and the resultant changes on UR business operations as described by both parties. To ensure consistency and reliability in our coding, we triangulated our coding scheme by cross checking data across multiple newspapers for each of the four South East Asian countries (See Table 1 and Appendices A and B for the sources and relevant links, respectively). We conducted 
coding on the perspectives provided by app founders and UR business owners to ensure that our coding and resultant conclusions were not reliant only on the perspective of the app founders or the app users. For example, if the app founders mentioned that using their apps would give UR businesses access to multiple suppliers, we ensured that UR businesses using the apps also mentioned that they were able to access multiple suppliers after using the apps. Moreover, the two researchers compared each other's coding to assess the reliability of coding and ensure internal consistency of the merged coding structure $[53,54]$.

The third part of the analysis was aimed at gaining a deeper understanding of the impact of digitisation of the overall performance of the UR businesses. To develop this deeper insight, we used a more structured second order analysis to examine the data at a higher level of theoretical abstraction [12]. Here, we used the method of constant comparison to discern second-order themes that subsumed the first order codes. This step allowed us to link the actions of the app founders and subsequent changes in UR business operations to actual pathways that led towards the economic and social transformation of UR businesses and their owners.

The fourth and final part of the analysis was aimed at more generally understanding the cumulative impact of the socio-economic transformations on the inclusive economic and social development and whether they were a local level pathway of achieving UN SDGs. To achieve this, we organised the second order data under the overarching themes of the UN SDGs. Here, we went backwards and forwards between our second order coding and appropriate literature on UN SDGs to identify the local level pathways embedded in the development of the digitised UR businesses.

In terms of data coding, we carried out both a first order and a second order analysis [12]. First, our data analysis involved a thorough coding of newspaper articles, social media sites and YouTube videos to develop first order codes. For example, the app founders often referred to 'The best part (at least for the stores) is deliveries are free of charge' to describe the key features of digitisation and its impact on UR businesses. Similarly, the app users referred to 'we were able to lower our costs without having to deal with inventory challenges' to describe the changes in business operations following digitisation. We used the language of the quotes from our data sources and combined them into informantcentric or first order codes with emphasis on the underlying meaning of the relevant quotes. Accordingly, we generated 20 first order open codes (listed in Table 2 to Table 7). Utilising the constant comparative method, we compared data across the quotes from app founders and app-using URs to understand how the concepts related to similar ideas or relationships. Second, the first order concepts guided us with initial understanding of the changes in UR business operations as a result of digitisation. To discern themes and form a detailed understanding of deeper patterns of relationships between the changes and the impact on economic and social outcomes, we used second order coding to examine the data at a higher level of abstraction [12]. We relied on a constant comparison to discern second order themes that subsumed the first order concepts. For example, 'sell products in bulk' was categorised under the first order open coded 'consolidated supply of products', indicating the positive economic outcomes experienced by UR owners after the digitised scaling of their businesses. A total of five second order themes were discerned from this process and are listed in Figure 1 below. Finally, we compiled all our second order themes into aggregate dimensions, which involved the task of examining the relationships between the first and second order theses to capture them under overarching economic and social outcomes linked to the UN SDGs. The final data structure is illustrated in Figure 1, which summarises the first and second order concepts and aggregate dimensions on which we built the theoretical framework (illustrated in Figure 2). 


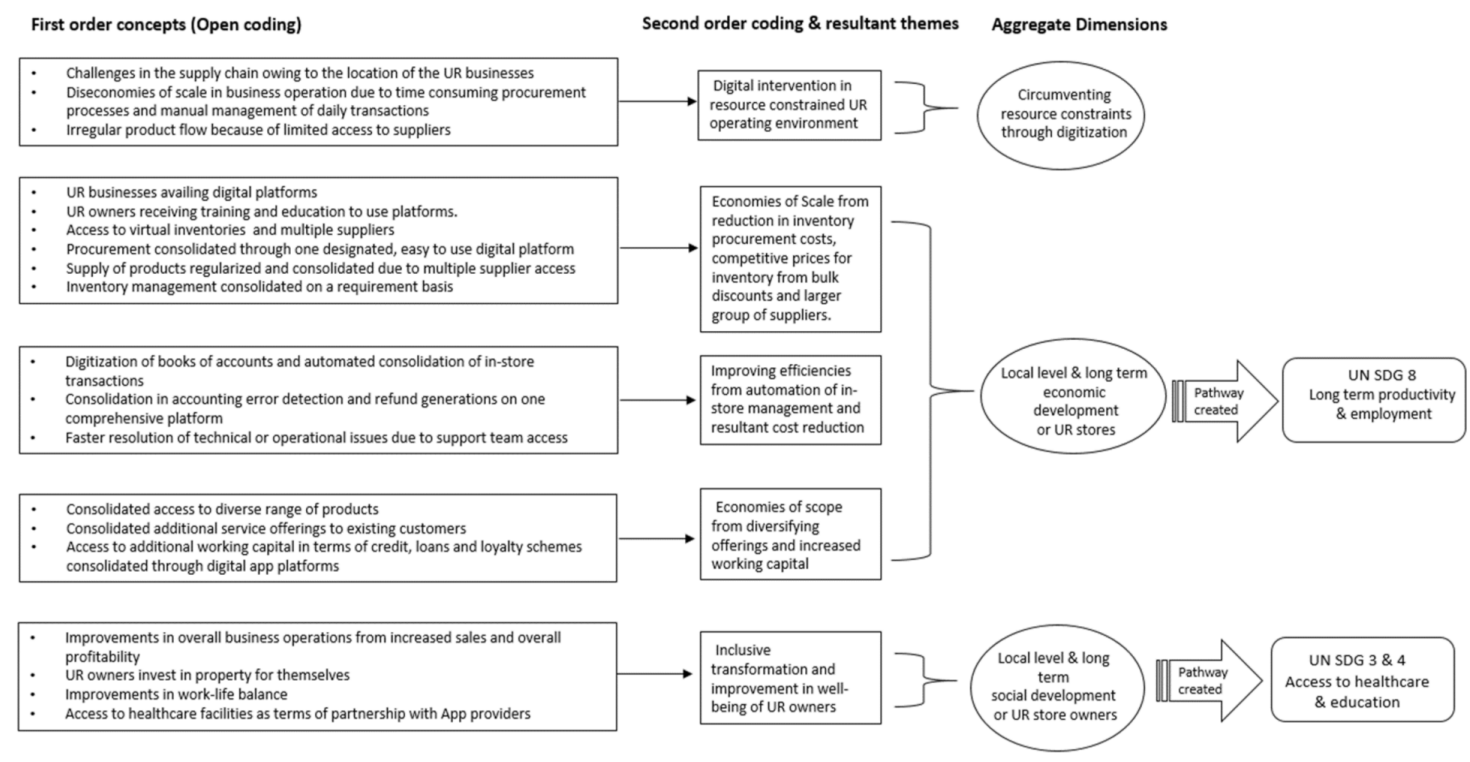

Figure 1. Summary of data analysis using the Gioian coding strategy.

\begin{tabular}{|c|c|c|c|c|c|}
\hline $\begin{array}{l}\text { Business } \\
\text { context of UR } \\
\text { businesses }\end{array}$ & $\begin{array}{l}\text { Base of pyramid UR } \\
\text { business model }\end{array}$ & App-based digital intervention & UR business consolidation & $\begin{array}{l}\text { Transformation in base } \\
\text { of pyramid UR business } \\
\text { model }\end{array}$ & UN SDGs \\
\hline $\begin{array}{l}\text { Limited access } \\
\text { to suppliers } \\
\text { Shop houses } \\
\text { Sole, } \\
\text { Subsistence } \\
\text { livelihood for } \\
\text { UR business } \\
\text { owners }\end{array}$ & $\begin{array}{l}\text { Fragmented business } \\
\text { model: Daily commute } \\
\text { for restocking of products } \\
\text { (increase transportation } \\
\text { costs); limited access to } \\
\text { suppliers; inconsistent } \\
\text { product flows. }\end{array}$ & $\begin{array}{l}\text { App Provider strategy: Low cost easy } \\
\text { to use digital platforms which can } \\
\text { overcome infrastructural and time } \\
\text { constraints and enable efficient } \\
\text { inventory management. } \\
\text { App provider action: Digital } \\
\text { onboarding of UR businesses, UR } \\
\text { owner digital literacy to enable } \\
\text { independent use of app-based } \\
\text { platforms. }\end{array}$ & $\begin{array}{l}\text { UR need: Easy re-stocking, savings on procurement } \\
\text { transportation costs, inefficient usage of } \\
\text { procurement time; regularize supply of products } \\
\text { UR business operations: Consolidated virtual } \\
\text { procurement gateway to network of multiple } \\
\text { suppliers, consolidate ordering process on a needs } \\
\text { to basis. Consolidate bulk discount on orders. } \\
\text { Consolidate regular supply of diverse range of } \\
\text { products, services }\end{array}$ & $\begin{array}{l}\text { Circumvent resource } \\
\text { constraints with digital } \\
\text { intervention }\end{array}$ & $\begin{array}{l}\text { Global Agenda for } \\
\text { 2030: Achieving } 17 \\
\text { Sustainable } \\
\text { Development Goals } \\
\text { by the year } 2030\end{array}$ \\
\hline & & $\begin{array}{l}\text { Pathway created: Scaling UR } \\
\text { businesses by expanding supplier base } \\
\text { for diverse inventory; reducing } \\
\text { inefficiencies in store and inventory } \\
\text { management; }\end{array}$ & $\begin{array}{l}\text { Pathway to transformation: } \\
\text { Improved conomic performance of business from } \\
\text { higher turnover, improved profits, reduction in } \\
\text { costs. Improved work-life balance, quality of life, } \\
\text { opportunities for education, creating personal } \\
\text { assets, healthcare from partnership with App } \\
\text { Providers }\end{array}$ & $\begin{array}{l}\text { Pathway to local level } \\
\text { socio economic } \\
\text { development: Economic } \\
\text { development (Growth of } \\
\text { businesses) } \\
\text { Social upliftment of UR } \\
\text { owners (Qual lity of life, } \\
\text { education, healthcare) }\end{array}$ & $\begin{array}{l}\text { UN SDG 8: Full and } \\
\text { productive } \\
\text { employment for UR } \\
\text { owners in future } \\
\text { UN SDG 4: } \\
\text { Education } \\
\text { UN SDG 3: Health } \\
\text { and wellbeing }\end{array}$ \\
\hline $\begin{array}{l}\text { Resource } \\
\text { shortage }\end{array}$ & $\begin{array}{l}\text { Inefficient business } \\
\text { operations, wastage } \\
\text { of time and resources }\end{array}$ & $\underset{\text { YES Is app-based digital }}{\text { Ynbes }}$ & $\begin{array}{l}\text { Are business processes in procurement and } \\
\text { inventory management consolidated? }\end{array}$ & $\begin{array}{l}\text { Inclusive economic } \\
\text { and social }\end{array}$ & $\begin{array}{l}\text { Local level pathway } \\
\text { to UN SDGS }\end{array}$ \\
\hline
\end{tabular}

Figure 2. Framework for the impact of app-based digitisation on UR businesses and resultant economic and social transformation.

\subsection{Establishing Robustness of Data Analysis}

In order to ensure that a robust data analysis process was adopted, we followed the tenets of Erlandson et al. [55] to ensure a robust data analysis by assessing the credibility, transferability, dependability and confirmability of our processes. Such an approach is more appropriate for conducting qualitative research where the primary rationale for the investigation is the exploration, understanding and development of new knowledge [56,57] and therefore different from the approach of using reliability and validity constructs in quantitative research. Moreover, we adapted Ishfaq et al.'s [58] application of credibility, transferability, dependability and confirmability of analytical process from their research on omni-channel supply chains in a retail context since our research context was also retail. Our data analysis processes were robust in four ways. First, as the various themes emerged from the coding process, the authors consensually agreed on the interpretations to establish credibility. Moreover, the content of the analysis was credible since they pertained to views expressed by the entrepreneurs (founders) and users of the digital platform. Second, the 
analysis focused on content pertaining to four separate countries in South East Asia. To that extent, the findings were transferable to the context of digitally equipped URs operating in low cost and underdeveloped business environments. Third, the data analysis covered a transformative period of two years following digital adoption by the small retailers, thereby highlighting the dependability of the findings. Finally, to establish confirmability of the data analysis, the authors provided a data structure (see Table 1) to demonstrate the abstraction of emerging concepts in the raw data and the eventual development of theoretical dimensions. The researchers sourced raw data for each retail example from multiple newspapers to avoid analytical bias stemming from limited evidence. To establish conformability of the findings, the researchers primarily coded themes common across the retail examples from all four countries.

\section{Findings and Analysis}

The first and second order codes extracted from the newspaper articles were aggregated to develop the theoretical framework we propose later in the paper. The open codes generated from the first level of analysis provide an initial insight into the different ways in which the digital platforms are enabling small retailers in the four countries to improve their operations, despite the chronic shortage of resources in their operating environment. During the second phase of data analysis, axial or second order coding was used to compare and contrast the first order codes with core concepts on consolidation of business operations and their implications on sustainable business model innovation in UR contexts. This process enabled the researchers to develop aggregate dimensions at a higher level of abstraction and assess the implications of digitisation of URs on economic and social sustainability. A summary of the first and second order codes, the resultant aggregate dimensions and their implications for the UN SDGs are provided in the table below. Detailed insights into the key findings are discussed in the following section.

\subsection{Open-Coding: UR Challenges, Digitisation, Consolidation of Procurement and Economies of Scale}

Challenges in UR Business Context

Our initial coding (see Table 2 below) highlighted similar chronic resource shortages to those reported in the academic literature. We found that the URs located in the four countries operate in business environments characterised by challenges of fragmented and time-consuming procurement (daily commute for stock procurement, transportation costs and time costs) and irregular supply of goods due to time-consuming procurement processes. The fragmented procurement process creates diseconomies of scale in the business operations which have an adverse impact on the profit potential. This is evident from the analysis of the app founders' views on UR businesses, which were echoed in the sample of testimonials from UR business owners about their business processes before they use digital apps. 
Table 2. Challenges to UR businesses (data sources available in Appendices A and B).

First Order Codes: UR Fragmented, Time-Consuming Procurement, Irregular Supply of Goods

App-Provider Perspective

'Our e-commerce marketplace allows producers across the country to continue selling their produce to wholesalers, retailers, and consumers during the Covid period, they added that

this initiative provides an alternative sales channel for producers and suppliers to sell their products online in bulk' (Founder of Malaysian

$$
\text { app-Appendix A F2) }
$$

"The idea is to have the people managing the small stores get access to products and services they can sell without having to have an inventory,

which is something that costs them a lot when it comes to starting a

business' (Founder of Indonesian app-Appendix A B5)

'Our App is a startup that addresses a simple painpoint in the typical sari-sari store business:

what if owners could choose the items they need to sell, order them online, and wait for them to be delivered, all without ever having to leaving their homes?' (Filipino app provider-Appendix A H2)

'Our mission to empower the large population of small retailers in Vietnam, who play an important role in our economy and the local neighbourhoods they serve.

The inventory supply chain in our country is very fragmented and these small retailers don't have a clear view of pricing, quality and even availability of most products' (Vietnamese app provider-Appendix A D5)

\section{App-User Perspective}

Open Coding

'We're flying high in terms of growth but the numbers don't feel right because of the hurdles of not big enough to source for ingredients at the lowest price point hence it plummets our margin every time' (Malaysian app user-Appendix B K3)

'The courier from the app company makes our distribution smoother (than before). Our customers are even more satisfied now' (Indonesia app user-Appendix B L2)

'Speedy transaction, lots of promotion, helpful call centre team with competitive price for prepaid' (Indonesia app user-Appendix B L2)

'Before, shopping to restock my store was difficult, because I would have to set aside a part of my day to actually go to the supermarket' (Filipino

UR owner 1 as per YouTube video testimonial-Appendix B M1)

'Our village is surrounded by mountains and my house is next to a river. Before I would need to go up the mountainand travel to the city to shop for goods to sell. But now it's better because the app provider just delivers it to us. It helped me save money on transportation' (Filipino UR owner 2 as per YouTube testimonial-Appendix B M1).

'Before this, we used to buy all our stocks from down the road and because of this we lose profit and we end up paying so much for transportation' (Filipino UR owner 1as per YouTube video testimonial-Appendix B M1)

Fragmented business/irregular supply of products

Irregular supply of products

Fragmented business/irregular supply of products

Fragmented business/irregular supply of products/time consuming procurement

Time consuming procurement

Time consuming procurement

Irregular supply of products/time consuming procurement

'The store is on the first floor and we live upstairs. Before I had to send text messages to all the suppliers,

for all different kinds of good, and that took several hours everyday'

(Vietnamese UR owner 1as per YouTube video testimonial-Appendix B J1) 


\subsection{Open Coding: Digitisation of UR Businesses}

Open coding of the newspaper articles (see Table 3 below) highlighted the app founders' strategic intent of improving the fragmented procurement by giving the URs access to wider and alternative channels for purchasing inventory that will save time and create more transparency in the process.

Table 3. App-based digital solutions (data sources available in Appendices A and B).

First Order Codes: Digital Onboarding, Digital Literacy, Simplified and Regularised Procurement

\begin{tabular}{c} 
App-Provider Perspective \\
\hline \\
'Through the use of technology and digitalisation, \\
warungs (the local name for mom and pop stores) \\
will be more competitive in facing the competition \\
with modern retail and also \\
giving added value to their consumers' \\
(Indonesian digital app provider-Appendix B B2)
\end{tabular}

'We teach them new skills such as online advertising because while they know how to advertise offline, online advertising can be an unfamiliar realm for local business owners. We want to help them become tech-savvy and master their online presence' (Malaysian app
provider-Appendix A F3)

‘Our digital platform began

building its retail network in July, aiming to connect manufacturers and shops through the app, which includes purchase and distribution functions'

(Vietnamese app provider-Appendix A D3)

'The core FMCG ordering already has a high retention rate and the addition of a

range of other features will likely improve it further. About $60 \%$ of stores that on boarded two years ago continue to order several times a week to a month on the app' (Filipino digital app provider-Appendix A H3)

\section{App-User Perspective \\ 'After joining the app \\ you can learn a lot about tips for managing a stall, as well as prices and types of goods' \\ (Indonesian app user-Appendix B L1) \\ 'It is \\ exiting to learn how digital business works, especially in shipping and distribution, which is very helpful to me' (Indonesian app user-Appendix B L1)}

'Never in my life I imagined that I would be able to take advantage of the digital platform, let

alone joining a (digital app) training' (Indonesian UR app user-Appendix B L2).

'The team is very proactive in helping me list my products on the App marketplace. This helps with my brand and product awareness on the platform. Looking forward to working closely with the team'

(Malaysian app user-Appendix B K2)

'Ever since MCO was announced in Malaysia, the App's team

has assisted us in digitalising our business units' (Malaysian UR app user 1-Appendix B K1).

'It's very pleased to know that the App provider also

cares about helping me managing store better' (Vietnamese UR app user 3-Appendix B J3)

'Only the App provider delivers to our area, before no one else would even dare delivery to our area because we are too far from the city'

(Filipino UR app user 3-Appendix B M1).
Digital on boarding and digital

literacy/simplified procurement

Digital on boarding and digital literacy

Digital on boarding, digital literacy, simplified procurement

Digital on boarding, digital literacy

Digital on boarding, digital literacy

Digital on boarding, digital literacy, simplified and regularised procurement

Our data analysis and subsequent coding of the UR owner testimonials highlighted that the app-based digital solutions create a digital ordering platform for the UR businesses. The UR owners receive training during the digital onboarding process through hands-on training and education to improve their vocational digital literacy. These digital ordering platforms are low-cost, easy to use platforms, aimed at simplifying the UR's procurement process, bypassing the infrastructural and time constraints and giving them access to a wider portfolio of virtual inventories held by suppliers and manufacturers across the breadth of the country. 


\subsection{Open Coding: Consolidation of UR Business operations}

\subsubsection{Consolidation of UR Procurement Processes}

Analysis of the newspaper data highlighted that the digital platforms create opportunities for access to virtual inventories, enabling the URs to consolidate their fragmented procurement process in three distinctive ways. First, in all four countries, the app-based ordering platforms provided a consolidated virtual and regular gateway to a network of suppliers. Second, ordering through an online platform of multiple suppliers allowed URs to consolidate the ordering process by assuming control of inventory procurement based on the convenience of time, as per the requirement. Third, access to multiple virtual vendors also enabled a consolidated and regular supply of products at comparative/optimum prices.

Review of the UR owner testimonials on the various social media sites confirmed that digitalisation improves fragmented procurement processes in three ways. First, the UR owners were able to access multiple sources of inventory from one digital platform, creating a consolidated virtual access to inventory. Second, multiple inventory access points regularised and consolidated the supply of products in bulk. Third, the UR can take complete control of the ordering process since they can use it from their mobile devices, and this adds flexibility and convenience to the ordering process. The resultant open codes are all summarised with corresponding data in Table 4 below.

\subsubsection{Consolidated Daily Bookkeeping and Inventory Management}

Analysis of the newspaper data highlighted that the digital platforms create opportunities to automate the routine business transactions in the everyday manual management of UR business operations. Our analysis revealed that the app founders viewed digitalisation as a means to simplify the daily management of store transactions while also creating more transparency in the UR supply chain.

Review of the app users' testimonials identified three ways in which they are able to consolidate the everyday management of their transactions and inventory. First, adoption of digital platforms enables the upgrading of manual bookkeeping to a centralised and efficient data management system for prompt information retrieval and sharing with customers. Second, automated bookkeeping allows the UR owners to calculate, detect and rectify errors in inventory calculation and available refunds where required. Third, technical issues with the app are resolved by dedicated customer support teams to enable the smooth functioning of the UR's daily business. The resulting open codes are all summarised with corresponding data in Table 5 below. 
Table 4. App-based digital solutions (data sources available in Appendices A and B).

First Order Codes: Consolidated Access to Suppliers, Consolidated Ordering Process, Consolidated Supply of Products

App-Provider Perspective

App-User Perspective

'Loved how easy it was to place an order using the digital platform! Saves me from ever running out of baking ingredients for my cake side business' (Malaysian UR owner 2 as per testimonial on app website-Appendix B K3)

'Our e-commerce marketplace allows producers across the country to continue selling their produce to wholesalers, retailers, and consumers during the Covid period, they added that this initiative provides an alternative sales channel for producers and suppliers to sell their products online in bulk' (Founder of Malaysian app-Appendix A F2).

‘Our platform offers warungs

access to a wider and more reliable range of wholesale inventory which they can order through the application. The goods are delivered to warungs with free delivery and cash on delivery options' (Indonesian

$$
\text { app provider-Appendix A B5) }
$$

'The startup does this through an app which partner stores can access. Stores order through the app and we deliver the items straight to the store the next day. The best part (at least for the stores) is deliveries are free of charge. Plus, there's the added convenience of not having to physically leave the store to go out and buy fresh merchandise. On our part because we can combine orders from multiple stores, we can buy the items at relatively lower prices, which is how the company earns (Filipino app provider-Appendix A H2).

'Shopkeepers use the app to order hundreds of items from suppliers, eliminating the need to contact them individually. They also use it to connect to another app used by 10 million retail shoppers to make payments' (Founders of Vietnamese app-Appendix A D1)
'With their great value proposition, we were able to lower down our costs without having to deal with inventory challenges, able to source for products in a manageable bulks' (Malaysian UR owner 5-Appendix B K3)

'The prepaid price is very competitive which helps in getting more customers. If you've become a Jempolan user you'll get lots of promotion and prizes which is not possible to get for other apps' (Indonesian UR owner as per social media testimonial-Appendix B L1)

'Until I learned about this app, even if I want to stay in bed all I have to do is order on the UR owner 1 in YouTube testimonial-Appendix B M1)

'late at night when I think of something to order, I can still place it using the app. Here I control my budget and my time' (Filipino UR owner 5 as per website testimonial-Appendix B M2)

'I no longer have to wait for an agent. Because of the app, I save my time' (Filipino UR owner 8 as per testimonial of app website-Appendix B M2)

'It (the app) helped me save money on transportation and increase my profit' (Filipino UR owner 2-Appendix B M2)

'The goods are cheap, the load and bills are also strong here with using the ordering app. It even has rebates' (Filipino UR owner 6 as per website testimonial-Appendix B M2)

'Ordering from the app is very convenient for us, when I see no more stock, I will mark to the system. In the evening I will double check if it is suitable with conditions, I will place orders. I will know how much I ordered and how much I need to pay. I can keep track of promotions' (Vietnamese UR owner 2 as per website testimonial-Appendix B J2) app on my cellphone. And they can immediately deliver the next day. I love it!' (Filipino
Open Coding

Consolidated access to suppliers/consolidated ordering process

Consolidated supply of products

Consolidated ordering process

Consolidated ordering process

Consolidated access to suppliers/consolidated ordering process

Consolidated ordering process

Consolidated ordering process

Consolidated access to suppliers/consolidated ordering process

Consolidated access to suppliers/consolidated ordering process 
Table 4. Cont.

First Order Codes: Consolidated Access to Suppliers, Consolidated Ordering Process, Consolidated Supply of Products App-User Perspective

Open Coding

'I can order anywhere, anytime via the App' (Vietnamese UR owner 3 as per website testimonial-Appendix B J3)

'I can order via the virtual store and track the order status to now when I can receive the products' (Vietnamese UR owner 4 as per testimonial on app website-Appendix B J3)

'Because I get to see all the prices of each product and I get to compare them to the prices in the supermarket. I don't mind if I only earn centavos for each sale, as long as it is consistent' (Filipino UR owner 2 as per website testimonial—Appendix B M1)

Consolidated access to suppliers/consolidated ordering process

Consolidated access to suppliers 
Table 5. First order codes for consolidated daily bookkeeping and inventory management (data sources available in Appendices A and B).

First Order Codes: Consolidate Bookkeeping, Efficient Inventory Management Systems, Resolution for Technical Problems

App-Provider Perspective

'When people talk about digital transformation, most of the time, they are focusing on potentially generating higher revenue or saving operational cost.

They don't focus too much on business continuity, but we know that this is equally crucial. Kakitangan's platform simplifies HR tasks by providing users with a single platform to manage payroll, benefits, employee information and more' (Malaysian app provider-Appendix A F3)

'The platform drives more frequent, larger orders with an intuitive user experience, helping to increase the customer's entire product line. It also assists them

to reduce up to $75 \%$ of their expenses associated with data entry, catalogue printing and

distribution, as well as costs related to fixing errors and managing back orders' (Malaysian app provider-Appendix A F6).

'Mom and pop retailers in Vietnam typically need to call 50 to 80 wholesalers and distributors to place individual orders, which can take up to a week to arrive. By aggregating demand, we are able to offer better and more transparent pricing. We are also building a network of warehouses to ensure next day delivery, which vastly improves a small shop owner's ability to manage both stock and cash flow' (Vietnamese app provider-Appendix A D5)

Mom and pops, known as warungs in the country, order goods from our platform, cutting out middlemen and local distributors. Our platform also offers cash back when orders are paid for with the app's electronic payment service. Partial refunds are given if an order placed in the morning does not arrive by the end of the day'. (Second Indonesian app provider-Appendix A B3)

'Our platform enables local mom and pop stores to better source products and manage their inventory in a efficient manner by predicting which products will be in high demand beforehand' (Founders of Malaysian app-Appendix A F3)

\section{App-User Perspective}

'Ever since MCO was announced in Malaysia, the app provider's team has assisted us in digitalising our business units. Now we are we able to manage our inventory efficiently' (Malaysian UR owner 1 testimonial on app website-Appendix B K1)

'Also, they have a great customer support team that always update me constantly and resolve any issues that I had' (Malaysian UR owner as per website testimonial—Appendix B K3)

'It's very pleased to know that the App also cares about helping me managing stores better. I don't have to use notebook for debts, orders management anymore, thanks to the App-books' (Vietnamese app user 5 as per website testimonial-Appendix B J3)

'Since having this app, as it has a website, all goods are saved on computer. In case there is any mistake, like shippers sent me wrong items, I can change. Now I spend only 10-15 minutes to choose items on the website' (Vietnamese UR owner 2 as per YouTube video testimonial-Appendix B J1).

'The app is complete and there is no need to wait for a signal because only wifi is needed. Unlike the SIM that is still waiting for the signal. I also use the e-list here' (Filipino app user 7 as per website testimonial-Appendix B M2)

'It is very good about timing, I will know the amount of goods I ordered, how much I need to pay, I saw that if I order, I can keep track of promotions and choose suitable price with my demands because I will know how much or how many percent promotions I chose cost me per unit of goods I ordered' (Vietnamese app user 1 as per YouTube video testimonial—Appendix B J2)

'Also, they have a great customer support team that always update me constantly and resolve any issues that I had' (Malaysian UR owner 3-Appendix B K1)

'Great product! Speedy transaction, lots of promotion, cheaper prepaid price and very friendly call centre team' (Indonesia UR owner as per social media testimonial-Appendix B L1)

'After joining the app you can learn a lot about tips for managing a stall, as well as prices and types of goods' (Indonesia UR owner as per social media testimonial—Appendix B L1)
Open Coding

Efficient inventory management

Resolution for technical problems

Consolidate

bookkeeping, efficient inventory management

Efficient inventory management

Efficient inventory management/resolution for technical problems

Consolidate bookkeeping, efficient inventory management

Resolution for technical problems

Efficient inventory management/resolution fo technical problems

Efficient inventory management 


\subsubsection{Consolidated Access to Diverse Product, Service and Working Capital}

Analysis of the newspapers highlighted that app providers aim to provide UR business owners access to a diverse range of product and services which they can offer their customers. The apps seek to transform the UR business owners into active participants in the marketplace, from where they can choose the appropriate (priced) product and service offerings for their end-users. Review of the testimonials from the UR owners highlighted three ways in which the use of apps enabled the UR owners to consolidate their offerings for their customers. First, the UR businesses can expand the portfolio of products they offer for their customers at competitive prices because of the transparency of pricing across virtual inventories accessible on the digital platforms. Second, the diverse product ranges are often available at promotional prices which can be sold to end consumers at cheaper prices. Third, the digital platforms give the URs renewed relevance as a one-stop service provider for digital services, including bill payments, mobile top ups, remittance facilities and Wi-Fi hotspots.

\subsubsection{Improvement in Livelihood of UR Owners}

Open coding of the newspapers identified the socially driven motivations of the app providers and their aims to improve the livelihoods of the UR owners by modernising their businesses. The apps seek to democratise the UR business operations by empowering storeowners, uplifting their lives and those of the communities served by them and giving them access to basic healthcare facilities. Review of the testimonials of the UR owners highlighted three ways in which the livelihoods of the UR business owners had improved after the digital modernisation of the UR businesses. First, the overall improvement in business performance owing to increased sales and profitability created financial opportunities for the UR owners to invest in home ownership. Second, improved efficiencies in business operations and the resulting time savings improved the work life balance of the women involved in the daily management of the UR stores. Third, partnering with app providers gave UR store owners access to improved healthcare facilities, owing to the welfare packages aligned with the partnership.

\subsection{Second Order Coding: Economic and Social outcomes from UR digitisation}

The first order coding described in the previous sections unveiled important elements of the app provider's rationale and strategy behind the digitisation of the UR businesses and impact on the UR's business operations. More specifically, the initial focus of open coding was to identify whether there was any consolidation in the backend functions and daily business operations of the UR businesses. For a deeper analysis to discern the implications of digitisation on the economic performance of UR businesses and overall transformation in the livelihood of UR business owners, we used constant comparison to discern the second order themes that subsumed the first order codes.

\subsubsection{Economic Outcome from Scaling Business}

Analysis of the newspapers highlighted that a fundamental rationale behind the conceptualisation of the apps was to enable the URs to scale up their businesses through securing virtual access to multiple inventories from a larger base of vendors. The notion of scaling of business rationale emerged from comparing various first order codes (Table 4) labelled as 'consolidated access to suppliers', 'consolidated ordering process' and 'consolidated supply of products', which pointed to expanded access to suppliers for UR businesses. Specific examples of data corresponding to our first order coding, which provided further rationale for the second order abstraction to scaling of UR businesses, were 'alternative sales channels', 'access to a wider and more reliable range of wholesale inventory' and 'shopkeepers use the app to order hundreds of items from suppliers' (see Table 4 for corresponding quotes).

Comparing the app-users' perspectives on scaling businesses to those of the UR owners' perspectives on consolidated procurement enabled us to surface the overarching 
theme of 'economies of scale' arising from scaling UR businesses (see Figure 1 under second order coding). Specific examples of data corresponding to our first order coding, which provided further rationale for the second order abstraction to economies of scale and reduction in inventory costs, were 'elimination of daily physical and transportation costs for procurement', 'immediate delivery' 'ordering from app is convenient', 'see no stock, I mark the system', 'bulk discounts/promotions on inventory procurement' and 'order anytime anywhere'. Another round of comparisons across UR owner testimonials on 'improved profitability' and 'increased turnover' and 'opened 4 stall branches', confirmed the positive economic outcome owing to economies of scale. (See Tables 4 and 6 for corresponding quotes).

\subsubsection{Economic Outcome from Automated Store Transactions}

Another theme that emerged from the second order coding pertained to the positive economic outcomes from app-developers' rationale to automate bookkeeping and inventory management to improve business efficiencies in day-to-day store transactions and operations. The notion of positive economic outcomes emerged from the first order codes, 'efficient inventory management', 'resolution for technical problems' and 'consolidate book keeping' (See Table 5). Specific examples of data corresponding to the first order coding, which provided further justification for the second order abstraction to 'business efficiency', were 'focus on business continuity', 'simplify HR tasks by providing users with a single platform', 'manage accounts receivables and payables in a more efficient manner' and 'reduce up to $75 \%$ of their expenses associated with data entry' (see Table 5 for corresponding quotes).

Further comparison of UR business owner perspectives on the consolidation of instore bookkeeping and inventory management enabled us to identify the overarching theme of 'improving efficiencies in business operations' from automated store transactions (see Figure 1 under second order coding). Specific examples of data corresponding to our first order coding, which provided further rationale for the second order abstraction to 'improved efficiencies in business operations, were 'no more notebooks', 'I can change (mistakes)', 'manage store better', 'get refunds', 'keep track of promotions' and 'instantaneous resolution'. Another round of comparisons of UR owner testimonials on 'lowering costs', 'saving costs', 'control budget', 'control time', confirmed the positive economic outcomes of improved efficiencies arising from reduction in costs associated with automating store operations in daily business transactions (see Tables 4 and 5 for corresponding quotes).

\subsubsection{Economic Outcome from New Business Opportunities}

A third theme that emerged from second order coding pertained to the app-developers' rationale for digitising UR businesses to improve economic outcome by creating 'economies of scope' from new business opportunities through diverse product and service offerings for the UR customers. The notion of positive economic outcomes of economies of scope afforded by new business opportunities emerged from the first order codes 'access to diverse products', 'access to diverse service offerings', 'access to credit' and 'access to working capital' (see Table 6). Specific examples of data corresponding to the first order coding, which provided further justification for the second order abstraction to 'economies of scope from new business opportunities', were 'help grow their revenue stream', 'added services stores can offer', 'offer credit line', 'embolden to try new products' and 'financial service offering' (see Table 6 for corresponding quotes). 
Table 6. First order codes for consolidated access to diverse product, service and working capital (data Sources available in Appendices A and B).

First Order Codes: Access to Diverse Product, Service Offerings, Working Capital/Credit

App-Provider Perspective

'Our digital platform offers risk-free returns on products so that local retailers are emboldened to try out new products and introduce them to their local communities' (Malaysian app provider-Appendix B F4).

'Expand the range of services, warungs can offer and

help them grow new revenue streams: In addition to existing services such as airtime, bill payments, travel tickets, remittance' (Indonesian app provider-Appendix B B2)

'Our revenue will be based on a targeted advertising platform, financial services offerings and market development for suppliers'

(Vietnamese app provider-Appendix B B3)

'Our platform is also offering stores a credit line that rides on the loyalty programme. Stores can apply for loyalty credit to fund their purchases on the app, with payments deducted from the margins the app provider shares with them'

(Filipino app provider-Appendix B H1)

App-User Perspective

Open Coding

'Best platform to purchase stocks for my business!

Offering great variety of products that allows me to restock my item easily and conveniently' (Malaysian UR app user 3-Appendix A K1)

'The (customer service) team is very proactive in helping me list my products' (Malaysian UR app user 2-Appendix B K1)

'There are lots of stock items and there are additional vouchers. I can also focus more on selling because I don't have to go shopping. As long as I use the app, the store is getting better' (Indonesian UR app user-Appendix B L1)

'There are so many reliefs that I feel like it's easy to stock items at affordable prices to free shipping.

The increase in turnover is no joke, from 1.5 million-2.5million to 3-5 million' (Indonesian Rupiah) per day. I have even opened 4 branches now' (Indonesian UR owner testimonial as per app website-Appendix B L1)

'Using this app I have been able to sell digital products, including phone credit top-up and digital financial transactions such as remittance to my customers. This service helps more customers, most of whom are sellers at the open market. They can

directly transfer money from their daily income easier without having to go to a bank' (Indonesian UR app user-Appendix B J2)

'The best thing about the app is that the prices and promotions are transparent to all retailers' (Vietnamese UR app user 4 as per website testimonial)

'It's (the online platform) really convenient-I don't have to spend three hours for shopping and commuting, The transportation costs I save on, I use to augment my working capital' (Filipino UR app user-Appendix B M2)

'My dream is to have everything available in my store, that I would have anything anyone will look for'

(Filipino app user 2-Appendix B M1)

'All we want is for it

(the store) to grow bigger and bigger' (Filipino app user 3-Appendix B M1)
Access to diverse products

Access to diverse products

Access to diverse products/ access to credit

Access to diverse products/service offerings

Access to credit

Create working capital

Access to diverse products/service offerings 
Further comparison of UR business owner perspectives on the consolidated access to diverse product and service offerings highlighted the ability to earn positive economic outcomes from expanding scope of customer experience management. Specific examples of data from first order coding, which provided further rationale for the second order abstraction to 'economies of scope from business opportunities', were 'this service helps customers', 'proactive listing of products', 'focus more on selling', 'get price list to customers at quicker pace', 'direct transfer of customers', daily income easier', 'augment working capital', 'increase turnover', 'increase profit', 'set up 4 shops' and 'make everything available in store'. Another round of comparison of UR owner testimonials confirmed the positive outcome of economies of scope from 'store getting better with variety of offers' and 'offering great variety to restock items conveniently' (see Tables 4 and 6 for corresponding quotes).

\subsubsection{Social Outcome from Inclusive Transformation of UR Owners}

A fourth theme that emerged from second order coding pertained to the app-developers' objective of inclusive UR business modernisation, which can positively transform overall well-being of UR owners. The notion of inclusive development of the UR business owners emerged from the open codes 'home ownership', 'work life balance', 'education' and 'access to healthcare'. Specific examples of data corresponding to the first order coding, which provided further justification for the second order abstraction to 'inclusive transformation', were 'create meaningful synergies between homemaker and businessman/woman', 'uplift life' 'transforming stores', 'promote welfare', 'provide support', 'grow together' and 'empower population' (see Table 7 for corresponding quotes).

Further comparison of UR business owner perspectives on 'work life balance', 'education' and 'access to healthcare' highlighted the positive outcome on their well-being. Specific examples of data from first order coding, which provided further rationale for the second order abstraction to 'well-being and overall transformation', were 'own property', 'expand my house', 'daughter finished studies', 'do so much more in life', 'more time for kids', 'siblings back in school' and 'ease burden of treatment'. Another round of comparison of UR owner testimonials confirmed the overall improvement in well-being and aspirations for 'buying house', 'making store bigger' and 'look for a job' (see Table 7 for corresponding quotes).

\subsection{Digitalisation of UR Businesses: Implications for UN Sustainable Development Goals}

In our final analysis, we amassed our second order themes into aggregate dimensions. This stage of the analysis involved another examination of the relationships among first order concepts and second order themes that could be captured into a set of simplified complementary groupings. The comparison of open and second order codes between app providers' rationale for digitising the UR businesses and its impact on UR business performance highlighted a pathway for sustainable economic and social development and the subsequent attainment of the UN SDGs [13].

The UR businesses' potential to become driving forces behind achieving the UN SDGs through local level economic development were embedded within the app providers' rationale of 'today's UR's contribute to economic development', 'transforming stores to uplift communities they serve' and 'digitally adapt in support of UN SDGs'. Further comparison with UR business owner perspectives highlighted the positive impact of digitisation on long economic growth and survival of UR businesses. These were highlighted in the data corresponding to open and second order codes, indicating 'higher sales turnover', 'opening 4 more stalls', 'improving profits', 'making store bigger' and 'store is getting better' and 'service helps more customers'. In the final analysis, the cumulative positive impact of digitisation on economic performance, long-term growth and prosperity of UR businesses were aggregated as 'local level sustainable economic development'. Economic sustenance of the UR businesses offering full and productive employment for UR owners would become a local level pathway towards attainment of the UN SDG 8 [13] in the long run. 
Table 7. First order codes for improvement to livelihood (data Sources available in Appendices A and B).

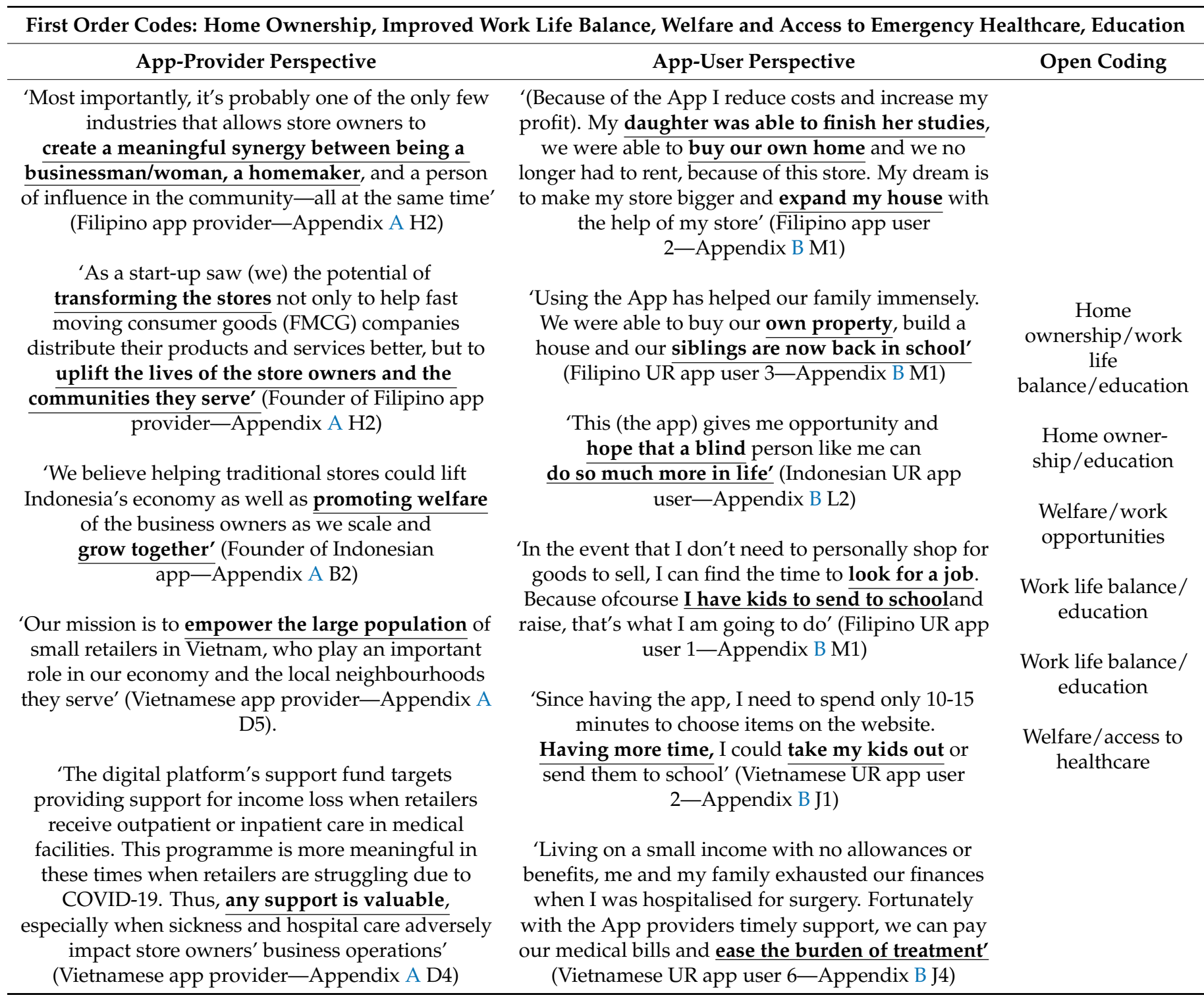

Lastly, the UR businesses' potential to become driving forces for achieving the UN SDGs [13] through local level social development were embedded within the app providers' rationale of 'promoting welfare', 'teach them new skills', 'use technology to become competitive' 'financing support in sickness and hospitalisation' and 'meaningful synergy between homemaker and businessman/woman' for UR business owners. Further comparison with UR business owner perspectives highlighted the social development enabled by digitalisation of UR businesses. These were highlighted in the data corresponding to open and second order codes indicating 'daughter was able to finish studies', 'siblings are now back in school', 'learn a lot of tips about managing stalls' and 'joining a digital app training'. The cumulative positive impact of digitisation on social development of the UR owners were aggregated as 'inclusive education' and 'lifelong learning', all of which created a local level pathway towards attainment of the UN SDG 4 [13] in the long run. Another element of the aggregated dimension 'social development' was improvement in well-being, which was highlighted by data corresponding to the open and second order coding indicated by 'having more time', 'take my kids out', 'send kids to school' and 'ease burden of treatment', all of which created the local level pathways towards attainment of the UN SDG 3 [13]. 


\section{Discussion}

In this paper, we asked how digitalisation enables UR businesses to consolidate their business operations to achieve economic and transformative social development and their relevant implications for sustainability. From our data analysis, we conclude that the consolidation of business operations enables the UR businesses to overcome fundamental inefficiencies in daily business operations enabling economies of scale and scope. Thus, improving the performance of UR businesses and the overall socio-economic situation of UR business owners which creates a local level pathway for the realisation of the UN SDGs [13]. What emerges from our analysis of UR digitisation in four South East Asian countries is a grounded process framework (Figure 2) which explains how digitisation enables UR businesses to circumvent resource shortage, consolidate procurement and inventory management, resulting in overall economic and social transformation for the UR businesses and their owners.

The initial analysis of UR business contexts highlighted that the inherent inefficiencies arise from the daily (transportation and purchase) costs of procuring products from suppliers, inconsistent product availability due to limited supplier access and time-consuming manual bookkeeping of transactions and inventory management. Gupta and Ramachandran [8] draw similar conclusions about the operating business model of URs from their review of the UR business context. The limited budgets on which the subsistence UR business owners manage the business are prohibitive of any future expansion or development. Our theoretical framework suggests that the app-based platforms are designed to transform UR businesses into quasi-digitised retailers who can overcome the inherent inefficiencies of their fragmented business models.

Our framework highlights that the app providers' overall strategic intent is to provide low-cost digital platforms, enabling a simple and easy onboarding of UR businesses. The UR owners are provided digital training and have access to service personnel for subsequent trouble shooting. Digital onboarding and digital literacy create a pathway for long term local level economic development in three ways. First, virtual onboarding scales up the UR businesses by opening a virtual gateway to multiple product suppliers. As a result, the previously time consuming and cost inefficient procurement processes are consolidated into digital platforms offering demand based, real time ordering facilities from a variety of suppliers at competitive prices. Over time, repeat usage of the platforms create opportunities for bulk discounts and scope for further reduction in procurement costs. Second, digital onboarding and the consolidation of inventory management and daily transactions in a singular digital platform reduce inefficiencies of manual operations and cumulatively reduce daily operating costs. Third, digital intervention also creates economies of scope by consolidating access to a wider portfolio of products and services for UR businesses to offer to their end consumers. Diversifying product and service offerings to end consumers therefore creates new opportunities for long-term growth of these businesses. The cumulative impact of consolidated procurement, automated consolidation of in-store transaction and inventory management and diversification of product/service offerings create a pathway of economic transformation from increased turnover and profits. The spill over effects of digitalisation are reflected in the improved work-life balance of UR business owners who transform into digitally empowered, wellinformed, proactive participants in the marketplace for goods procurement. Overall improvement in the financial situation of UR business owners makes education affordable for younger family members, gives access to healthcare (depending on terms of partnership with app providers) and improves overall security and stability in the lives of the UR business owners. Accordingly, our framework highlights that the socio-economic impact of UR business transformation and resultant opportunities for long term employability, education and well-being create local level pathways for attainment of the UN SDGs 3, 4 and 8 within economies where these businesses dominate the retail landscape.

Our framework extends the work from Adhikary et al. [6] and Gupta and Ramachandran [8] on economic benefits of digitisation for UR businesses by responding to their call 
for research into the impact of digitisation on upstream activities of UR businesses. Adhikary et al. [6] and Kumar et al. [7] show the positive relationship between UR's adoption of digital payment technologies and their economic performance. In essence, their study focuses on the impact of digitisation on the downstream value chain activities in relation to efficient handling of payments from customers. Our research supplements the work by Adhikary et al. [6], Gupta and Ramachandran [8] and Kumar et al. [7] by showing the economic and social benefits URs can gain by adopting app-based digitalisation to consolidate their upstream procurement functions, in-store inventory management and diversifying their product, service offerings. Accordingly, our framework highlights that the consolidation of procurement on app-based digital platforms enable UR businesses to realise economies of scale and scope while reducing inefficiencies in in-store management. The subsequent improvements in business performance create future growth opportunities for the UR businesses and make healthcare and educational opportunities more accessible to the UR owners. Finally, our paper studies app-based digitisation of UR businesses in four South East Asian emerging markets. By doing so, we extend the burgeoning studies on UR digitisation to a wider base of emerging markets compared to the India focus of existing studies, which is a limitation of Adhikary et al.'s [6] research, acknowledged by the authors themselves.

\section{Theoretical Implications}

With this study, we contribute to the existing literature in two ways. First, our framework adds to the literature of sustainable business model innovation $[1,3]$ by showing that the adoption of app-based digital platforms enables resource constrained businesses to 'circumvent' chronic constraints and improve overall the socio-economic performance of UR communities. More specifically, it extends the discourse on business model innovation resulting in consolidation of business processes. Our framework highlights how app-based digitalisation consolidates upstream procurement of URs by linking them to multiple suppliers enabling UR businesses to realise economies of scale and scope and improve business profitability.

Second, we contribute to the emergent literature on inclusive and transformative models of innovation in emerging or transforming economies [11,14]. We respond to Mortazavi [11] and Mihalache and Volberda's [14] call to explore the mechanisms of innovation which empower communities and create transformative opportunities for overall improvement in livelihoods. Our findings show that app-based digitisation is inclusive because it democratises the UR business operations by opening up opportunities for these businesses to compete in the free marketplace and secure diverse range of products at competitive prices to sell to their end consumers. The resultant economic benefits from improved turnover and profitability creates a domino effect, transforming the livelihoods of UR business owners. Our framework for sustainable business model innovation at the base of the pyramid therefore provides a new perspective on digital interventions, leading to inclusive and transformative models of UR business innovation in emerging economies.

\section{Practical Implications}

The findings in this paper have at least three practical ramifications which we outline in the following section. First, digital transformation of the widely present URs in the South East Asian markets [6,31,32] has the potential to contribute to the UN SDGs 3, 4 and 8 [13] through the local level pathways of socio-economic development of UR businesses and their owners. This pathway for achieving the UN SDGs [13] can create an opportunity for local level entrepreneurs and policy makers to collaborate on innovative initiatives for inclusive and transformative development of subsistence and rural communities. While the onus continues to be on governments to devise and implement policies for attainment of the UN SDGs [13], nurturing the talent and entrepreneurial spirit of the subsistence communities can be a practical, effective and parallel pathway for achieving these goals. 
Second, the consolidation of URs also has implications for local procurement strategies, especially in times of crisis, such as the ongoing pandemic. As the new normal of the post pandemic world evolves in the near future, local procurement strategies will become integral to the continuance of businesses and livelihoods while catering to the basic needs of consumers. The findings of this research bring to the fore the significant role URs can play in contributing to resilient South East Asian economies in the future.

Third, digitisation can cut across local boundaries and percolate regional economies, thereby opening new trade channels across regional countries. Connecting the subsistence market UR businesses to vendors and last mile consumers in regional ASEAN markets can open up new markets for URs. This can create a parallel regional trade channel between the widely prevalent URs operating in resource-constrained environments. These trade channels could also act as buffers to support economic and regional growth in a post pandemic world as economies focus on their own recovery, prioritising local and regional trade over international trade.

\section{Limitations, Future Research and Concluding Remarks}

Despite unveiling a number of important findings, this study does have limitations. First, the data was sourced primarily from secondary resources. To develop a more nuanced and detailed insight into the digitised business operations of URs, the researchers would advocate a longitudinal qualitative and quantitative empirical research project covering an eighteen-month period. This would provide the details necessary to develop a more insightful value co-creation model for app-based digital UR businesses.

Second, this research focused on the socio-economic impact of digitisation on UR businesses and their owners. Future research could also include detailed investigations into the socio-economic impact of digitisation on the other stakeholders in this network, namely the UR customers, vendors, the supply chain/logistics providers and the businesses providing the apps.

To conclude, the objective of this study was to develop a theoretical framework exploring the impact of digitisation on UR businesses and the implications for sustainable business model innovations at the base of the pyramid. The framework that is developed underscores the impact of digitisation in circumventing resource constraints, consolidating business operations of UR businesses and creating local level pathways to economic and social transformations proposed by the UN SDGs.

Author Contributions: Conceptualization M.M., methodology M.M., validation M.M. and J.W.; formal analysis M.M. investigation M.M.; resources M.M.; data curation M.M.; writing-original draft preparation, M.M.; writing-review and editing M.M. and J.W. All authors have read and agreed to the published version of the manuscript.

Funding: This research received no external funding.

Institutional Review Board Statement: Ethical review and approval were waived for this study, due to use of publicly available secondary resources as data sources.

Informed Consent Statement: Not Applicable.

Data Availability Statement: Not Applicable.

Acknowledgments: Not Applicable.

Conflicts of Interest: The authors declare no conflict of interest.

\section{Appendix A. Links to Verify Data Sources and Data Triangulation}

The following 65 newspapers articles were used for analysis

A. General on South East Asia (four links in total)

1. https://www.wsj.com/articles/bettin-on-southeast-asias-e-commerce-boom-146108 5962 
2. https://www.wsj.com/articles/BL-DGB-36377

3. https://www.straitstimes.com/opinion/the-digital-developing-economy-south-eastasia-in-five-objects

4. http://www3.weforum.org/docs/WEF_Future_of_Consumption_in_Fast_Growth_ Consumer_Markets_ASEAN_2020.pdf

B. Indonesian app links (16 in total): Links for quotes used as data source

1. https://www.bbc.com/news/business-43667202

2. https://e27.co/kudo-becomes-grabkios-marking-new-offers-aimed-at-larger-kiosksdigitisation-20191108/

3. https://asia.nikkei.com/Business/Business-trends/Mom-and-pop-2.0-Asia-s-traditionalretailers-embrace-tech

4. https://kr-asia.com/kudo-ceo-agung-nugroho-growing-with-grab-to-win-in-the-southeastasian-market

5. https://e27.co/agung-nugroho-on-kudos-latest-innovation-and-keeping-tabs-on-financialinclusion-for-all-20190517/?utm_content=buffer9b8ce\&utm_medium=social\&utm_source= twitter.com\&utm_campaign=buffer

6. https://www.marketing-interactive.com/indonesian-o2o-platform-kudo-rebrandsto-grabkios-aims-to-empower-warungs

7. https://techcrunch.com/2017/02/13/grab-kudo/

8. https://www.straitstimes.com/asia/se-asia/kudo-to-grab-in-battle-for-indonesianmarket

9. https://www.businesstimes.com.sg/transport/ride-hailing-firm-grab-agrees-to-buyindonesian-payment-startup-kudo

C. Indonesian app links: Links for data triangulation sources

1. https://kr-asia.com/as-millions-come-online-each-year-rural-indonesia-is-in-for-monumen changes

2. https://www.mime.asia/grab-collaborated-with-pertamina-to-give-loans-to-grabkiospartners/

3. https://kr-asia.com/indonesian-o2o-platform-kudo-rebrands-itself-into-grabkios-bykudo

4. https://www.oecd.org/coronavirus/policy-responses/e-commerce-in-the-time-of-covid19-3a2b78e8/\#section-d1e526

5. https://jakartaglobe.id/tech/techsavvy-warungs-to-take-major-leap-toward-digitaleconomy/

6. https://www.thejakartapost.com/life/2021/04/15/grassroot-strategy-to-realize-financialinclusion-in-indonesia.html

7. https://campaignbriefasia.com/2019/09/12/omg-indonesia-sets-record-in-digitalinnovation-by-launching-first-ever-programmatic-dooh-campaign-in-indonesia-withlemma/

8. https://www.cnbc.com/2021/02/02/bukalapak-indonesias-multibillion-dollar-warunge-commerce-business.html

D. Vietnam data source links (14 links): Links for quotes used as data source

1. https://en.vietnamplus.vn/vinshop-breathes-fresh-air-into-traditional-retail-market/ 194325.vnp

2. https://www.retailnews.asia/vingroup-app-to-digitise-300000-vietnamese-mom-andpop-shops/

3. https://asia.nikkei.com/Business/Technology/Vingroup-app-digitizes-mom-and-popshops-in-Vietnam

4. https://vir.com.vn/telio-care-supports-struggling-local-retailers-during-covid-19-8 3135.html

5. https://vir.com.vn/vietnams-first-b2b-e-commerce-platform-telio-gunning-for-expansion72594.html 


\section{E. Vietnam data source links: Links for data triangulation sources}

1. https://vietnamnet.vn/en/business/household-groceries-compete-equally-with-modernretail-chains-675671.html

2. https://kr-asia.com/vingroup-app-digitizes-mom-and-pop-shops-in-vietnam

3. https://www.techinasia.com/crazy-competitive-market-vietnams-momandpop-shops

4. https://vir.com.vn/telio-announces-telio-care-fund-to-ensure-business-continuity-forsmall-retailers-82188.html

5. https://thesupplychainlab.blog/2020/07/20/vietnams-telio-ecommerce-for-mom-andpop-groceries/

6. https://www.dealstreetasia.com/stories/b2b-ecommerce-firms-vietnam-209867/

7. https://asia.nikkei.com/Business/Retail/Vingroup-taps-Vietnam-s-mom-and-popstores-in-retail-comeback

8. https://asianbusinessmen.com/vingroup-taps-vietnams-mom-and-pop-stores-in-retailcomeback/

9. https://kr-asia.com/vietnamese-b2b-e-commerce-platform-telio-raises-usd-25m-seriesa

F. Malaysia links (18 links): Links for quotes used as data source

1. https://www.theedgemarkets.com/content/advertise/next-step-malaysias-digitaltransformation

2. https://www.theedgemarkets.com/article/using-tech-tackle-pandemicrelated-disruptionmalaysias-food-supply-chain

3. https://www.theedgemarkets.com/article/startups-riding-digitalisation-wave

4. https://absolutemarket.org/news/enabled-by-artificial-intelligence-malaysia-basedb2b-marketplace-startup-dropee-aims-to-empower-mom-and-pop-stores-in-the-region/

5. https://retailinasia.com/in-tech/dropee-launches-full-release-of-its-b2b-marketplace/

6. https://www.theedgemarkets.com/article/dropee-early-execution-key

7. https://www.uob.com.my/about/news/2020/press-release-nov26-2020.page

G. Malaysia links: Links for data triangulation sources

1. https://thefullfrontal.my/the-future-of-malaysian-farmers-how-can-we-help/

2. https://www.retailnews.asia/dropee-launches-full-release-b2b-marketplace-new-webinterface/

3. https://kr-asia.com/bukalapaks-revenue-grew-35-in-1h-2021-on-the-back-of-o2o-business

4. https://www.digitalnewsasia.com/digital-economy/dropee-partners-ministry-agriculturehelp-farmers-fishermen

5. https://kr-asia.com/bukalapaks-revenue-grew-35-in-1h-2021-on-the-back-of-o2o-business

6. https://www.dropee.com/pages/dropee-partners-with-uob-to-simplify-trading-andwholesale-for-businesses-to-thrive-through-banking-and-digital-solutions /

7. https://www.malaymail.com/news/malaysia/2021/08/10/a-look-at-the-four-malaysianstartups-listed-by-forbes-as-among-100-to-watc/1996559

8. https://themalaysianreserve.com/2021/08/11/malaysian-start-ups-on-forbes-asias100-to-watch-list/

9. https://www.nst.com.my/lifestyle/pulse/2018/11/430563/dropee-ceo-and-co-founderlennise-ng-singing-completely-different

10. https://www.theborneopost.com/2020/11/30/uob-malaysia-partners-dropee-to-helpretailers-wholesalers-digitalise-and-optimise-businesses-while-saving-costs /

11. https://thefintechtimes.com/women-in-fintech-lennise-ng-from-malaysia/

H. Philippines Links (13 articles): Links for quotes used as data source

1. https://www.techinasia.com/talk/philippine-ecommerce-rely-convenience-stores

2. https://www.esquiremag.ph/money/industry/growsari-startup-profile-a00289-202 00715-lfrm

3. https://the-ken.com/sea/story/growsaris-key-to-the-philippines-sari-sari-treasure/

I. Philippines Links: For data triangulation sources 
1. https://www.manilatimes.net/2021/06/22/business/corporate-news/growsari-raisesover-30-b-in-funds / 1804162

2. https://manilastandard.net/mobile/article/362910

3. https://business.inquirer.net/329657/theres-money-in-linking-sari-sari-stores-to-supplychains

4. https://techcrunch.com/2021/06/21/growsari-a-b2b-platform-for-small-stores-inthe-philippines-adds-investors-like-temaseks-pavilion-capital-and-tencent/

5. https://www.straitstimes.com/asia/se-asia/small-businesses-in-se-asia-turn-to-techas-insolvencies-loom

6. https://businessmirror.com.ph/2021/06/22/growsari-raises-30-million-to-supportexpansion/

7. https://variablemag.com/fintech/growsari-giving-sari-sari-stores-a-fighting-chancewith-technology /

8. https://news.abs-cbn.com/business/07/09/21/growsari-sari-sari-stores-growth

9. https://manilastandard.net/mobile/article/303186

10. https://wavemaker.vc/sea/transforming-traditional-trade-spotlight-on-b2b-startupgrowsari/

\section{Appendix B. Additional Social Media Sources and YouTube Links for Perspectives from App Users}

J. Vietnam-App-user perspectives

1. YouTube Video link: https://www.youtube.com/watch?v=3FuBDEKiVBE

2. Translated video link 1: WhatsApp Video 2021-09-02 at 18.12.06.mp4

3. Translated video link 2: WhatsApp Video 2021-09-02 at 18.12.09.mp4

4. Corporate website testimonials https://www.telio.vn/en

K. Malaysia-App-user perspectives

1. https://www.dropee.com/features

2. https://www.dropee.com/services

3. https://dropee.business.site/

L. Indonesia-App-user perspectives

1. https://warungpintar.co.id/

2. https://www.facebook.com/pg/JUPISS.ID/reviews/?ref=page_internal

M. Philippines-App-user perspectives-video

1. YouTube Video links https://www.youtube.com/watch?v=ckuV7esPYaw

2. Social Media Testimonials https://business.growsari.com/about-growsari/

\section{References}

1. Holtström, J. Business model innovation under strategic transformation. Technol. Anal. Strateg. Manag. 2021. [CrossRef]

2. Hamel, G.; Prahalad, C.K. Leading the Revolution; Harvard Business School Press: Boston, MA, USA, $2000 ;$ pp. 343-354.

3. Sinkovics, N.; Gunaratne, D.; Sinkovics, R.; Molina-Castillo, F.-J. Sustainable Business Model Innovation: An Umbrella Review. Sustainability 2021, 13, 7266. [CrossRef]

4. Shakeel, J.; Mardani, A.; Chofreh, A.G.; Goni, F.A.; Klemeš, J.J. Anatomy of sustainable business model innovation. J. Clean. Prod. 2020, 261, 121201. [CrossRef]

5. Langley, P.; Leyshon, A. The Platform Political Economy of FinTech: Reintermediation, Consolidation and Capitalisation. New Politi-Econ. 2021, 26, 376-388. [CrossRef]

6. Adhikary, A.; Diatha, K.S.; Borah, S.B.; Sharma, A. How does the adoption of digital payment technologies influence unorganized retailers' performance? An investigation in an emerging market. J. Acad. Mark. Sci. 2021, 49, 882-902. [CrossRef]

7. Kumar, V.; Nim, N.; Sharma, A. Driving growth of Mwallets in emerging markets: A retailer's perspective. J. Acad. Mark. Sci. 2019, 47, 747-769. [CrossRef]

8. Gupta, S.; Ramachandran, D. Emerging Market Retail: Transitioning from a Product-Centric to a Customer-Centric Approach. J. Retail. 2021. [CrossRef] 
9. Viswanathan, M.; Rosa, J.A.; Ruth, J.A. Exchanges in marketing systems: The case of subsistence consumer-merchants in Chennai, India. J. Mark. 2010, 74, 1-17. [CrossRef]

10. Peprah, A.A.; Giachetti, C.; Larsen, M.M.; Rajwani, T.S. How Business Models Evolve in Weak Institutional Environments: The Case of Jumia, the Amazon.Com of Africa. Organ. Sci. 2021. [CrossRef]

11. Mortazavi, S.; Eslami, M.H.; Hajikhani, A.; Väätänen, J. Mapping inclusive innovation: A bibliometric study and literature review. J. Bus. Res. 2021, 122, 736-750. [CrossRef]

12. Gioia, D.A.; Corley, K.G.; Hamilton, A.L. Seeking qualitative rigor in inductive research: Notes on the Gioia methodology. Organ. Res. Methods 2013, 16, 15-31. [CrossRef]

13. United Nations Sustainable Development Goals. Available online: https:/ / www.un.org/sustainabledevelopment/ (accessed on 7 July 2021).

14. Mihalache, O.R.; Volberda, H.W. Business Model Innovation in Transforming Economies: A Co-evolutionary Perspective for a Global and Digital World. Manag. Organ. Rev. 2021, 17, 202-225. [CrossRef]

15. Casadesus-Masanell, R.; Zhu, F. Business model innovation and competitive imitation: The case of sponsor-based business models. Strat. Manag. J. 2013, 34, 464-482. [CrossRef]

16. Bocken, N.M.P.; Short, S.W.; Rana, P.; Evans, S. A literature and practice review to develop sustainable business model archetypes. J. Clean. Prod. 2014, 65, 42-56. [CrossRef]

17. Curtis, S.K.; Mont, O. Sharing economy business models for sustainability. J. Clean. Prod. 2020, 226, 121519. [CrossRef]

18. Tukker, A. Eight types of product-service system: Eight ways to sustainability? Experiences from SusProNet. Bus. Strat. Environ. 2004, 13, 246-260. [CrossRef]

19. Balocco, R.; Cavallo, A.; Ghezzi, A.; Berbegal-Mirabent, J. Lean business models change process in digital entrepreneurship. Bus. Process. Manag. J. 2019, 25, 1520-1542. [CrossRef]

20. Geissdoerfer, M.; Vladimirova, D.; Evans, S. Sustainable business model innovation: A review. J. Clean. Prod. 2018, 198, 401-416. [CrossRef]

21. Jabłoński, A.; Jabłoński, M. Trust as a key factor in shaping the social business model of water supply companies. Sustainability 2019, 11, 5805. [CrossRef]

22. Sharmelly, R.; Ray, P.K. Managing resource-constrained innovation in emerging markets: Perspectives from a business model. Technol. Soc. 2021, 65, 101538. [CrossRef]

23. Williamson, P.J.; Wan, F.; Eden, Y.; Linan, L. Is disruptive innovation in emerging economies different? Evidence from China. J. Eng. Technol. Manag. 2020, 57, 101590. [CrossRef]

24. Neumann, L.; Winterhalter, S.; Gassmann, O. Market maketh magic-consequences and implications of market choice for frugal innovation. Int. J. Technol. Manag. 2020, 83, 55-77. [CrossRef]

25. Agarwal, N.; Chakrabarti, R.; Prabhu, J.; Brem, A. Managing Dilemmas of Resource Mobilization Through Jugaad: A MultiMethod Study of Social Enterprises in Indian Healthcare. Strat. Entrep. J. 2020, 14, 419-443. [CrossRef]

26. Zhu, F.; Zou, S.; Xu, H. Launching reverse-innovated product from emerging markets to MNC's home market: A theoretical framework for MNC's. Int. Bus. Rev. 2017, 26, 156-163. [CrossRef]

27. Winterhalter, S.; Zeschky, M.B.; Neumann, L.; Gassmann, O. Business Models for Frugal Innovation in Emerging Markets: The Case of the Medical Device and Laboratory Equipment Industry. Technovation 2017, 66, 3-13. [CrossRef]

28. Pansera, M.; Owen, R. Framing resource-constrained innovation at the 'bottom of the pyramid': Insights from an ethnographic case study in rural Bangladesh. Technol. Forecast. Soc. Chang. 2015, 92, 300-311. [CrossRef]

29. Ray, P.K.; Ray, S. Resource-Constrained Innovation for Emerging Economies: The Case of the Indian Telecommunications Industry. IEEE Trans. Eng. Manag. 2009, 57, 144-156. [CrossRef]

30. Raghavendra, R.H. An Overview of Unorganised Retail Sector in India. ELK Asia Pac. J. Mark. Retail. Manag. $2004,5,5$.

31. Mukherjee, M.; Cuthbertson, R. Applying the scenarios method to capture uncertainties of retail development in emerging markets. Int. Rev. Retail. Distrib. Consum. Res. 2015, 26, 323-346. [CrossRef]

32. Euromonitor. Top 100 Retailers in Asia 2021. Available online: https://go.euromonitor.com/white-paper-retailing-210525-top_ 100_retailers_in_asia_2021.html?utm_source=Top_100_Retailers_Asia_2021\&utm_medium=press \%20release\&utm_campaign= CT_WP_21_05_25_Top\%20100\%20Retailers\%20Asia\#download-link (accessed on 29 June 2021).

33. Bronnenberg, B.J.; Ellickson, P.B. Adolescence and the Path to Maturity in Global Retail. J. Econ. Perspect. 2015, $29,113-134$. [CrossRef]

34. Reinartz, W.; Dellaert, B.; Krafft, M.; Kumar, V.; Varadarajan, R. Retailing Innovations in a Globalizing Retail Market Environment. J. Retail. 2011, 87, S53-S66. [CrossRef]

35. Sinha, P.K.; Gokhale, S.; Rawal, S. Online Retailing Paired with Kirana-A Formidable Combination for Emerging Markets. Cust. Needs Solut. 2015, 2, 317-324. [CrossRef]

36. Bijmolt, T.H.; Broekhuis, M.; De Leeuw, S.; Hirche, C.; Rooderkerk, R.P.; Sousa, R.; Zhu, S.X. Challenges at the marketingoperations interface in omni-channel retail environments. J. Bus. Res. 2021, 122, 864-874. [CrossRef]

37. Viswanathan, M.; Rosa, J.A. Product and market development for subsistence marketplaces: Consumption and entrepreneurship beyond literacy and resource barriers. In Product and Market Development for Subsistence Marketplaces; Jose, R., Madhu, V., Eds.; Emerald Group Publishing Limited: Bingley, UK, 2007; pp. 1-17. 
38. Hammond, A.L.; Kramer, W.J.; Katz, R.S.; Tran, J.T.; Walker, C. The Next 4 Billion. Innov. Technol. Gov. Glob. $2007,2,147-158$. [CrossRef]

39. Ruth, J.A.; Hsiung, R.O. A family systems interpretation of how subsistence consumers manage: The case of South Africa. In Product and Market Development for Subsistence Marketplaces; Jose, R., Madhu, V., Eds.; Emerald Group Publishing Limited: Bingley, UK, 2007; pp. 59-87.

40. Sheth, J.N. Impact of Emerging Markets on Marketing: Rethinking Existing Perspectives and Practices. J. Mark. 2011, 75, 166-182. [CrossRef]

41. Yu, H.-C.; Hsi, K.-H.; Kuo, P.-J. Electronic payment systems: An analysis and comparison of types. Technol. Soc. 2002, 24, 331-347. [CrossRef]

42. Worlds Payments Report. Cap Gemini and BNP Paribas. Available online: https://worldpaymentsreport.com/wp-content/ uploads/sites/5/2018/10/World-Payments-Report-2018.pdf (accessed on 2 July 2018).

43. Ernst and Young. Covid-19: How to Build Supply Chains Resilient to Disruption. Available online: https://www.ey.com/en_sg/ consulting/how-to-build-a-supply-chain-thats-resilient-to-global-disruption (accessed on 2 July 2021).

44. Risselada, H.; Verhoef, P.; Bijmolt, T.H. Dynamic Effects of Social Influence and Direct Marketing on the Adoption of HighTechnology Products. J. Mark. 2014, 78, 52-68. [CrossRef]

45. Ernst and Young. SMEs in Southeast Asia: Redesigning for the Digital Economy. Available online: https://www.ey.com/en_sg/ growth/growth-markets-services/ey-smes-in-southeast-asia-redesigning-for-the-digital-economy (accessed on 2 July 2021).

46. Sanders, M.; Cheng, J.; Unnikrishnan, S.; Keswakaroon, D. The Future of Retail in Asia-Pacific: Digital Leaders, Fast Modernizers and More. Available online: https://www.bain.com/insights/the-future-of-retail-in-asia-pacific-snap-chart/ (accessed on 12 July 2020).

47. Statista. Modern Grocery Retail (MGR) Penetration Forecast for ASEAN-5 in 2021 by Country. Available online: https:/ /www. statista.com/statistics / 857417/asean-5-modern-grocery-retail-penetration-forecast-by-country/ (accessed on 6 July 2021).

48. Statista. Indonesia's Preferred Buying Channels from 2016-2019. Available online: https://www.statista.com/statistics/1115109/ indonesia-preferred-buying-channels / (accessed on 6 July 2021).

49. Statista. Food Retail Sales in the Philippines in 2015 by Outlet Type. Available online: https://www.statista.com/statistics/7154 41/food-retail-sales-value-of-in-the-philippines-by-outlet-type/ (accessed on 6 July 2021).

50. Statista. Preference for Retail Trade Channels in Vietnam in 2020, by City. Available online: https:/ /www.statista.com/statistics / 1110961/vietnam-preference-of-retail-channels-by-city/ (accessed on 6 July 2021).

51. Teng, L.J. SME up against a Wall. The Edge, Malaysia. 5 April 2020. Available online: https://www.theedgemarkets.com/article/ smes-against-wall (accessed on 6 July 2021).

52. Locke, K. Grounded Theory in Management Research; SAGE: London, UK, 2003.

53. Strauss, A.; Corbin, J. Basics of Qualitative Research Techniques; SAGE Publications: Thousand Oaks, CA, USA, 1998.

54. Miles, M.B.; Huberman, A.M. Qualitative Data Analysis: An Expanded Sourcebook; Sage: London, UK, 1994.

55. Erlandson, D.A.; Harris, E.L.; Skipper, B.L.; Allen, S.D. Doing Naturalistic Inquiry: A Guide to Methods; Sage: London, UK, 1993.

56. Upright, P.A.; Forsythe, S.A. A Review of Qualitative Research in Sport Management: Utilizing a Descriptive Case Study Design. Ky. SHAPE J. 2021, 58, 64-70.

57. Lincoln, Y.S.; Guba, E.G. Naturalistic Inquiry; Sage: London, UK, 1985.

58. Ishfaq, R.; Davis-Sramek, E.; Gibson, B. Digital supply chains in omnichannel retail: A conceptual framework. J. Bus. Logist. 2021. [CrossRef] 